\title{
Fulfillment of IFRS 2 Disclosure Requirements by Companies Listed on the Prague Stock Exchange
}

\author{
Martin Červeny"
}

\begin{abstract}
:
The aim of this paper is to assess the quality of share-based payments' disclosure in compliance with IFRS 2 by companies listed on the Prague Stock Exchange. The study shows how companies in the Czech market utilizing share-based payments meet the requirements given by IFRS 2 framework and in order to support the arguments, it compares the results with randomly selected companies from the German DAX index, which represents a well-developed market. The focus is on three key principles of disclosure, as defined by the IFRS 2. As we will demonstrate, Czech corporations do meet the regulatory minimum requirements, but they fail to utilize some of the advanced valuation methods and their reports are generally rather brief compared to their German counterparts.
\end{abstract}

Key words: IFRS 2; Share-Based Payments; Employee Stock Options.

JEL classification: M40.

\section{Introduction}

Options and stocks granted to executives and employees by market-leading companies have been wildly debated by both theoreticians and professionals over the past several decades. Some believe that this form of compensation commonly referred to as share-based payments is an effective tool of employee motivation and remuneration, incentivizing the staff to take actions resulting in shareholders' value maximization.

First to suggest employee stock options as a possible solution to the principalagent problem were Jensen \& Meckling (1976). Agency theory indicates that there is a risk of managerial mischief when the interests of owners (principals) and managers (agents) differ. Thus, it suggests an alignment of their interests through equity ownership. Otherwise, this separation of interests could result in such managerial actions that would be suboptimal with respect to the shareholders' value maximization principle. Managers with fixed cash salaries restricted solely by ineffective external control mechanisms could incline to empire-building and

Martin Červený; University of Economics Prague, Faculty of Finance and Accounting, Department of Corporate Finance, W. Churchill Sq. 4, 13067 Prague, Czech Republic, <cerveny@zkdusek.com>.

The article is processed as an output of the research project under the institutional support VŠE IP100040 of the Faculty of Finance and Accounting, University of Economics, Prague. 

Stock Exchange.

enjoy other private benefits, or they would be simply reluctant to take desirable actions at all. Number of empirical researches confirmed this hypothesis. To name a few: Demsetz \& Lehn (1985); Himmelberg, Hubbard \& Palia (1999); Core \& Guay (1999), Rajgopal \& Shevlin (2002), more recently Pendleton \& Robinson (2010).

Effects of employee stock option grants have been discussed in numerous financial journals, since there is a parallel stream of empirical research suggesting these means of compensation fail to motivate managers to the extent some initially expected. Particularly, concerns over the generosity of compensation are common, especially in times following the recent crisis, when such levels of compensation expenditures seemed excessive compared to average corporate performance metrics. The former practices had been blamed to cause greediness, excessive risk taking, and shortsightedness in the financial sector (Nyberg et. al., 2010). At the same time, managers deliberately influenced the way these share-based payments were disclosed for the public, which even deepened the issue with unlimited control over their own pays through rent extraction (Bebchuk et. al., 2002). The standard FAS 123 Accounting for Stock Based Compensation published in 1995 only encouraged companies to treat stock option grants as expenses. It is no longer a secret that this was a direct result of excessive lobbying by interested parties, mostly preparers of financial statements. Most firms, not quite surprisingly, would still use the intrinsic value approach, which biased the overall financial picture of companies (Hull \& White, 2002).

Chalmers \& Godfrey (2005) estimated that the obligatory IFRS 2 adoption had adversely affected at least $20 \%$ of firm's financial performance ratios. An example how stock option grants can impact financial position of a company can be AOL Warner, which in 2001 reported the operating profit of $\$ 700$ million under the accounting rules effective at that time. If we applied today's valuation principles, the company would have reported an operating loss of $\$ 1.7$ billion for the same period (Bodie et. al., 2003).

After several infamous accounting scandals, such as the bankruptcy of Enron in 2001, critics started to point out there was a serious threat of moral hazard related to employee shares and stock options, and called for a systematic change in the way these instruments should be disclosed in companies' financial statements (Healy \& Palepu, 2003). These long demanded changes took place in 2004, along with the introduction of the revised standard FAS 123 in US GAAP (ASC 718 today) and with the brand new IFRS 2 crafted by the International Accounting Standards Board (IASB). The new standards introduced a revolutionary way of valuation for share based compensation - the fair value approach, one that better reflects their effects on entities' income and wealth positions. Interestingly, 
the IFRS 2 is not limited to employees since virtually any payment made in company's capital instruments is subject to this standard.

These days, there is little doubt about ESOs being costs to the company, which arises at the time of grant - not on the later day of the potential exercise (Giner $\&$ Arce, 2012). There is, however, more controversy regarding the valuation itself, as there is a significant discretion over the choice of inputs (Chebotareva, 2016). Correct valuation should not just provide estimates that reflect the cost of the options, but it should be reproducible and verifiable by a third party as well. Admittedly, usage of some advanced valuation techniques not only provides better estimates of the true value of share-based remuneration, but it also allows for a certain level of profit and loss optimization (Amman \& Seiz, 2005). The goal of this article is not to continue in the never ending discussion on the correct valuation methods - the article is about the correct way of disclosing the methods used, as required by the IFRS 2. To this date, just a handful of empirical researches have assessed how companies meet the requirements in specific markets. Horton \& Serafeim (2008) presented one of the pioneering researches on mandatory IFRS adoption and transition in general. They noticed that much had not changed for the UK companies in the matter of employee stock options' treatment. Perhaps, this was due to the fact that the UK has been traditionally one of the most developed markets in the world with high share of multinational corporations and sophisticated investors. Melis \& Carta (2009) examined up to seventy companies in the Italian market between the years 2004 and 2005 to discover a major shift in the way share-based payments were disclosed. They concluded that the adoption of IFRS 2 led to a significant improvement since a vast majority of corporations was forced to cease using the intrinsic value approach. According to their findings, the new regulation has contributed towards revealing the true cost of share-based remuneration and reduced the information asymmetry between corporate outsiders and insiders. Arguably, these new conditions might lead to a decrease in the total volume of employee stock options granted, as these lose their attraction the moment they are recognized as an expense (Atan et. al., 2010).

Corporations in countries with the most developed markets have gradually adapted to the new rules and there is evidence that these changes have led to a higher standard of financial reporting practice worldwide. The question that remains unclear is whether the situation differs in countries with a significantly shorter tradition of capital markets where share-based compensation is scarce and unknown to the general investing public. The aim of this article is to examine whether the fulfilment of IFRS 2 disclosure requirements is significantly lower in one of these markets - namely the Prague Stock Exchange - than what is in one of the most developed markets in the world - the Frankfurt Stock Exchange. 
Červený, M.: Fulfillment of IFRS 2 Disclosure Requirements by Companies Listed on the Prague Stock Exchange.

\section{Data and Methodology}

\subsection{Research Question and Dataset}

As discussed before, the research question for this paper will be as follows:

"Is the quality of disclosure in compliance with IFRS 2 by companies from a developed market superior to the information disclosed by companies listed on the Prague Stock Exchange?"

For the analysis part, the reports of corporations listed on the Prague Stock Exchange published between the years 2013 - 2015 will be assessed. The threeyear period was used in order to assess whether any significant changes took place over time. At the date of publication, there were currently 25 listings registered and actively traded on the PSE according to the central registrar (ČNB, 2017; PSE, 2017). This number had been narrowed down to eight companies that were utilizing some form of share-based payments in at least one year during the respective period. In addition, one listing was excluded as a non-domestic company reporting under US GAAP. See Appendix 1 for a list of companies used in the assessment.

For our study, the DAX index of the Frankfurt Stock Exchange will be considered a well-developed market. To represent the DAX, three corporations subject to reporting under IFRS 2 have been selected on a random basis and their 2015 annual reports were analyzed. Since the purpose of this study is to assess whether basically any company from the German market discloses in a higher standard of quality, we believe it is a reasonable simplification to pick corporations from the well-developed market randomly. Detailed analysis of the DAX corporations will be a subject of our future research.

\subsection{Reporting Requirements}

IFRS 2 lays the foundations for disclosure requirements in Article 44 and following. The requirements are built upon three following principles:

Principle I. founded by Article 44 requires entities to disclose all information that enables users of financial statements to understand the nature and extend of sharebased payment arrangements that existed during the respective period. The objective of this principle is to encourage corporations to describe the basic features to the general investing public including vesting conditions, methods of settlement, and any stock option details if applicable.

Principle II. is defined in Art. 46. According to this principle, users should be able to understand how the fair value of goods or services received, or the fair value of the equity instruments granted during the period was determined. To fulfill the 
principle, an entity should not only disclose the valuation model, but all model inputs as well, with the emphasis on volatility estimates.

Principle III. (Art. 50) demands information that enables public to understand the effect of share-based payment transactions on the entity's profit or loss for the period and on its financial position to be disclosed. The principle, however, does not explicitly state a binding rule how share-based payments should be treated.

For our analyses, each principle will serve as a standalone evaluation criterion. See Tables 1 and 2 in the following section to find the specific checklists for each of the first two principles. For every year and each market, number of corporations fulfilling the respective item is stated. In the analysis part, we will examine what share of companies does meet the respective principles in order to find the answer for our research question. In case of the third principle, we will proceed with a discussion regarding the optimal way of expensing share-based payments.

\section{Results and Discussion}

\subsection{Understanding the Nature and Extent of Share-Based Payments}

According to the empirical findings, the most preferred type of share-based payments is the managerial stock option plan (MSOP), which represented at least $50 \%$ of all types on the PSE every year. Employee stock plans follow with two occurrences each year, representing at least $25 \%$. In 2014, one corporation added a management stocks plan in addition to its existing MSOP. Quite surprisingly, one corporation on the PSE trades its own stocks in exchange for consulting services.

Similar observations can be made on the German market, where $67 \%$ were management stock option plans and 33\% employee stocks. These findings confirm the theoretical belief stating that management stock options are the most popular form of managerial motivation and remuneration, arguably this is because they appear relatively cheaper at the time of grant compared to giving out stocks directly.

Quite regrettably, domestic companies do struggle with disclosing the general description in a way that might jeopardize the first principle. Even though at least $86 \%$ of corporations do include some sort of general terms and conditions in their annual reports, just $43 \%$ in 2013 and 50\% in the following years deal with vesting conditions of these instruments. Similar numbers $(57 \%$ in $2013,63 \%$ in the following years) can be observed in disclosing the maximum term of these instruments and the expected method of settlement. Just 38\% (29\% in 2013) of all corporations include further description of share-based payments such as data breakdown, information regarding historical option plans, or corresponding future 
Červený, M.: Fulfillment of IFRS 2 Disclosure Requirements by Companies Listed on the Prague Stock Exchange.

outlooks. All DAX companies meet these requirements flawlessly as they include exhaustive, several pages long reports on remuneration in their annual reports.

Corporations that utilize stock options do meet the regulatory standards with a single exception - just 50\% of relevant PSE corporations fail to disclose the spot price at the date of exercise of options. This drawback puts a mist on insider transactions as it is difficult to estimate the actual profit harvested by the executives at the date of exercise.

\section{Tab. 1 Understanding the Nature and Extent}

\begin{tabular}{lllllllll}
\hline Evaluation criteria & $\mathbf{2 0 1 3}$ & $\mathbf{\%}$ & $\mathbf{2 0 1 4}$ & $\mathbf{\%}$ & $\mathbf{2 0 1 5}$ & $\mathbf{\%}$ & $\mathbf{D A X}$ & $\mathbf{\%}$ \\
\hline Share-based payment type - total: & 7 & 100 & 8 & 100 & 8 & 100 & 3 & 100 \\
- Employee stocks plan & 2 & 29 & 2 & 25 & 2 & 25 & 1 & 33 \\
- Management stocks plan & 0 & 0 & 1 & 13 & 1 & 13 & 0 & 0 \\
- Employee stock options plan & 0 & 0 & 0 & 0 & 0 & 0 & 0 & 0 \\
- Management stock options plan & 4 & 57 & 4 & 50 & 4 & 50 & 2 & 67 \\
- Pay for services in shares & 1 & 14 & 1 & 13 & 1 & 13 & 0 & 0 \\
Description: & & & & & & & & \\
- General terms and conditions & 6 & 86 & 7 & 88 & 7 & 88 & 3 & 100 \\
- Vesting conditions & 3 & 43 & 4 & 50 & 4 & 50 & 3 & 100 \\
- Maximum term & 4 & 57 & 5 & 63 & 5 & 63 & 3 & 100 \\
- Method of settlement & 4 & 57 & 5 & 63 & 5 & 63 & 3 & 100 \\
- Other & 2 & 29 & 3 & 38 & 3 & 38 & 3 & 100 \\
Option details (if applicable): & & & & & & & & \\
- Exercise prices of options & 4 & 100 & 4 & 100 & 4 & 100 & 2 & 100 \\
- Price at the date of & 2 & 50 & 2 & 50 & 2 & 50 & 2 & 100 \\
exercise/options & 4 & 100 & 4 & 100 & 4 & 100 & 2 & 100 \\
\hline
\end{tabular}

Source: Annual reports, authorial computation.

To sum up the key findings regarding the first principle, domestic companies have showed serious drawbacks in reporting details of share-based payments apart from general terms and conditions. The reason for this is that their remuneration/sharebased payment reports are mostly brief, put together just so that they satisfy the minimal requirements of their auditors, and fail to reflect the perspectives of outside users of financial statements.

\subsection{Understanding the Valuation}

Theoretically, disclosures of valuation should be assembled in such manner that enables general investing public and the creditors to understand the logic behind the models used and their respective inputs. In practice, we can hardly expect annual reports to substitute academic publications in this field, yet the reasoning 
still should be well-rounded and explained in a clear form. Table 2 displays the results of valuation assessment.

Only one company uses the direct method of valuation permitted by IFRS $2-$ clearly it is the same corporation that is able to measure the fair value of received consulting services directly (see previous section). $86 \%$ (88\% in the later years) of corporations measure the fair value of options and stocks using the indirect method of valuation. Selected DAX companies measure the value of options in $67 \%$ of cases, and the value of stocks in $33 \%$.

\section{Tab. 2 Valuation methods and inputs}

\begin{tabular}{lllllllll}
\hline Evaluation criteria & $\mathbf{2 0 1 3}$ & $\mathbf{\%}$ & $\mathbf{2 0 1 4}$ & $\mathbf{\%}$ & $\mathbf{2 0 1 5}$ & $\mathbf{\%}$ & DAX & \% \\
\hline Direct method & 1 & 14 & 1 & 12 & 1 & 12 & 0 & 0 \\
Indirect method & 6 & 86 & 7 & 88 & 7 & 88 & 3 & 100 \\
Model - indirect method (total): & 6 & 100 & 7 & 100 & 7 & 100 & 3 & 100 \\
- Black Scholes & 3 & 50 & 3 & 43 & 3 & 43 & 0 & 0 \\
- Binominal & 1 & 17 & 1 & 14 & 1 & 14 & 0 & 0 \\
- Monte Carlo & 1 & 17 & 1 & 14 & 1 & 14 & 2 & 67 \\
- Observable market price & 1 & 17 & 2 & 29 & 2 & 29 & 1 & 33 \\
- Not disclosed & 1 & 17 & 1 & 14 & 1 & 14 & 0 & 0 \\
Inputs - options only (total): & 4 & 100 & 4 & 100 & 4 & 100 & 2 & 100 \\
- Exercise price & 4 & 100 & 4 & 100 & 4 & 100 & 2 & 100 \\
- Life of the option & 3 & 75 & 4 & 100 & 4 & 100 & 2 & 100 \\
- Weighted average share price & 4 & 100 & 4 & 100 & 4 & 100 & 2 & 100 \\
- Volatility & 4 & 100 & 4 & 100 & 4 & 100 & 2 & 100 \\
- Risk free rate & 4 & 100 & 4 & 100 & 4 & 100 & 2 & 100 \\
- Expected dividends & 3 & 75 & 4 & 100 & 4 & 100 & 2 & 100 \\
- Volatility estimation explained & 1 & 25 & 2 & 50 & 2 & 50 & 1 & 50 \\
Modifications & 2 & 29 & 2 & 25 & 2 & 25 & 2 & 67 \\
\hline Sourc Ann
\end{tabular}

Source: Annual reports, authorial computation.

Companies in the domestic market prefer using the basic models of option valuation: simple Black-Scholes model (43\% in 2015), binominal model (14\% in 2015), while just one corporation claims it combines the advanced Monte Carlo simulation with the basic valuation model (no details included). Figures are stable for all the respective years. The Standard does not prefer a specific model, but there is an important caveat. Simple Black-Scholes model does not allow for all specifics of employee stock options such as vesting conditions, or early exercise, which can potentially lead to a significant underestimation of the corresponding expenses. Companies from the DAX, on the other hand, use the Monte Carlo simulation whenever they value stock options. 

Stock Exchange.

During the relevant period, Czech companies were relatively precise in disclosing the inputs for options explicitly required by the Standard. One exception could be observed in 2013, when one company failed to disclose the expected life of the options granted and the expected dividend yield. This deficiency has been mended since the following year. DAX companies disclose all of the basic inputs with no difficulties.

What all corporations from both the PSE and the DAX seem to struggle with, is a proper disclosure of the expected volatility. According to the Standard, an entity is required to explain in detail, how the anticipated volatility was estimated, and to what extend it is based on the historical volatility. Some corporations do indicate that the estimate is derived from the historical volatility, yet they fail to label the periods used for the calculations. Such practice does not allow for an effective control, and therefore it cannot be considered in compliance with the second principle. Only $25 \%$ of Czech companies disclosed the volatility estimate properly in 2013, this number grew to 50\% in 2014 and 2015. Similar proportion applied to the DAX companies (just 50\% do it right).

Corporations are also required to disclose any modifications made during the year in order to enhance the transparency and fairness of remuneration during the whole existence of the instruments. Only $29 \%$ domestic companies had a detailed report on modifications, while the rest resigned to verbal description. $67 \%$ of the DAX companies met this requirement.

Even though the domestic corporations disclose all the basic inputs for valuation, and at a first glance the reports appear to be complete, there is a significant difference from the DAX companies that go beyond the minimal requirements of the Standard and aim for an accurate, elaborated and well-explained estimate.

\subsection{Impacts On Income Statement and Balance Sheet}

Annual reports that we have examined never fail to disclose the total expense resulting from the share-based payments granted in a given year, perhaps as it is something demanded by the auditors. Given the various characteristics, certain companies might choose to include the managerial remuneration in personnel cost, while in different situations it might be more appropriate to treat these transactions as operating expenses.

Arguably, treating these costs separately might be the most preferable way of disclosure from the perspective of the financial statements' user. This practice was implemented by a single domestic corporation. Most domestic corporations (71\%), however, treat these costs as a part of personnel costs due to the fact these instruments are usually a form of personnel remuneration. German companies disclose these instruments in equity in $67 \%$, where they point out possible dilution 
effect on the corporate capital. In 2013, one domestic corporation assigned the costs in operating costs. This practice has been changed since 2014, when it started to treat share-based payments as a part of equity.

\section{Fig. 1 Methods of Expensing Share Based Payments}

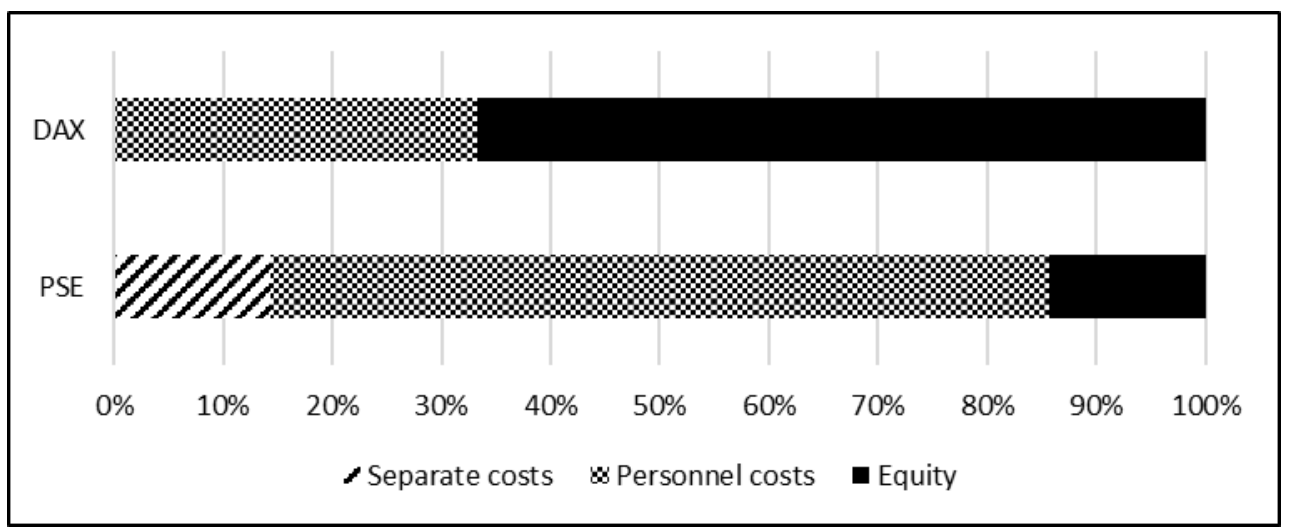

Source: Annual reports, authorial computation.

\section{Conclusion}

The research question stated upfront asked whether the quality of disclosure in compliance with IFRS 2 by companies from a developed market is superior to the information reported by companies listed on the Prague Stock Exchange.

Before answering the question, we need to make clear that the framework laid down by the IFRS 2 standard does not represent the ideal state of disclosure, but more of a minimum requirement for disclosing in order to ensure transparency and reliability of financial statements. Domestic companies listed on the Prague Stock Exchange mostly meet these minimum requirements, as these are demanded and monitored by the auditors. Even though there are some problematic areas, with individual companies mostly, there are no systematic troubles with disclosing the general terms, and most of the inputs (perhaps with the exception of volatility estimates). Also, the practices have remained barely unchanged between the three years, because domestic companies simply recycle their valuation templates with no efforts to upgrade the outputs.

The DAX companies, however, truly do represent the long-term well-developed market. The clear distinction between the domestic and the foreign market is that foreign corporations include exhaustive reports on share-based payments in their annual reports so that all of the users of financial statements can get a clear idea about the remuneration and compensation granted to every executive in the corporation. In our paper, we have revealed certain areas, where the companies 
Červený, M.: Fulfillment of IFRS 2 Disclosure Requirements by Companies Listed on the Prague Stock Exchange.

from the well-developed market excelled, for example when using more advanced valuation techniques, in disclosing volatility estimated completely, or in the perfectly described procedures how the fair value of non-option instruments is estimated. Even though we realize the limitations of our research, especially due to the limited sample of the DAX companies, important implications for the domestic market can be obtained. These final remarks indicate that the quality of IFRS 2 reporting is still superior in long-term well-developed markets, even though some differences might be more of a subjective nature that is sometimes difficult to quantify.

\section{References}

Amman, M., Seiz, R., 2005. An IFRS 2 and FASB 123 (R) compatible model for the valuation of employee stock options. Swiss Society for Financial Market Research 4, 381-396. DOI: 10.1007/s11408-005-6458-2.

Atan, R., Jasni N. S., Shahwan, Y., 2010. The Impact of IFRS 2 "Share-Based Payment" on Malaysian Companies. Review of Pacific Basin Financial Markets and Policies 3, 449-468. DOI: 10.1142/s0219091510002025.

Bebchuk, L. A., Fried, J. M., Walker, D. I., 2002. Managerial power and rent extraction in the design of executive compensation. National bureau of economic research 69, 751-846. DOI: 10.3386/w9068.

Bodie, Z., Kaplan, R. S., Merton, R. C., 2003. For the Last Time: Stock Options Are an Expense. Harvard Business Review 3, 63-71. DOI: 10.2469/dig.v33.n3.1327.

Chalmers, K., Godfrey, J. M., 2005. Expensing stock-based payments: A material concern? Journal of International Accounting, Auditing and Taxation 2, 157-173. DOI: 10.1016/j.intaccaudtax.2005.08.004.

Chebotareva, N., 2015. IFRS 2 Share-Based Payment research project: Report on research. IASB Agenda. Available from: <https://www.iasplus.com/engb/publications/global/reports/rep1398>. [14 January 2017].

Core, J., Guay, W., 1999. The use of equity grants to manage optimal equity incentive levels. Journal of Accounting and Economics 2, 151-184. DOI: 10.1016/s0165-4101(99)00019-1.

Czech National Bank (ČNB), 2016. Mandatory Data Published by Public Companies. Prague, Czech Republic. Available from: <http://www.cnb.cz/cs/ind ex.html>. [26 December 2016]. 
Demsetz, H., Lehn, K., 1985. The structure of corporate ownership: Causes and consequences. The Journal of Political Economy 6, 1155-1177. DOI: $10.1086 / 261354$.

Giner, B., Arce, M., 2012. Lobbying on Accounting Standards: Evidence from IFRS 2 on Share-Based Payments. European Accounting Review 4. 655-691. DOI: $10.1080 / 09638180.2012 .701796$.

Healy, P. M., Palepu, K. G., 2003. The fall of Enron. Journal of Economic Perspectives 2, 3-26. DOI: 10.1257/089533003765888403.

Himmelberg, C. P., Hubbard, R. G., Palia, D., 1999. Understanding the determinants of managerial ownership and the link between ownership and performance. Journal of Financial Economics 3, 353-384. DOI: $10.1016 / \mathrm{s} 0304-405 \times(99) 00025-2$.

Horton, J., Serafeim, G., 2010. Market reaction to and valuation of IFRS reconciliation adjustments: first evidence from the UK. Review of Accounting Studies 4, 725-751. DOI: 10.1007/s11142-009-9108-5.

Hull, J., White, A., 2002. Accounting for Employee Stock Options: A Practical Approach to Handling the Valuation Issues. Journal of Derivatives Accounting 1, 3-9. DOI: $10.1142 / \mathrm{s} 0219868104000026$.

Jensen, M. C., Meckling, W. H., 1976. Theory of the firm: Managerial behavior, agency costs, and ownership structure. Journal of Financial Economics 4, 305-360. DOI: $10.1016 / 0304-405 x(76) 90026-x$.

Melis, A., Carta, S., 2009. Does accounting regulation enhance corporate governance? Evidence from the disclosure of share-based remuneration. Journal of Management \& Governance 4, 435-446. DOI: 10.1007/s10997-009-9107-8.

Nyberg, A. J., Fulmer, I. S., Gerhart, B., Carpenter, M. A., 2010. Agency theory revisited: CEO return and shareholder interest alignment. Academy of Management Journal 5, 1029-1049. DOI: 10.5465/amj.2010.54533188.

Pendleton, A., Robinson, A., 2010. Employee stock ownership, involvement, and productivity: An interaction-based approach. Industrial \& Labor Relations Review 1, 3-29. DOI: 10.1177/001979391006400101.

Prague Stock Exchange (PSE), 2017. Market data. Available from: <https://www.pse.cz/udaje-o-trhu/akcie/prime-market/>. [17 January 2017].

Rajgopal, S., Shevlin, T., 2002. Empirical evidence on the relation between stock option compensation and risk taking. Journal of Accounting and Economics 2, 145-171. DOI: 10.1016/s0165-4101(02)00042-3. 
Červený, M.: Fulfillment of IFRS 2 Disclosure Requirements by Companies Listed on the Prague Stock Exchange.

Appendix 1: Overview of Companies

\begin{tabular}{|c|c|c|c|c|}
\hline \multirow{2}{*}{ Company } & \multirow{2}{*}{ Market } & \multicolumn{3}{|c|}{ Share-based payments } \\
\hline & & 2013 & 2014 & 2015 \\
\hline BOREALIS & PSE & $\checkmark$ & $\checkmark$ & $\checkmark$ \\
\hline CETV (GAAP) & PSE & & & \\
\hline ČEZ & PSE & $\checkmark$ & $\checkmark$ & $\checkmark$ \\
\hline Erste & PSE & & & \\
\hline Fortuna & PSE & & & \\
\hline Kofola & PSE & & & \\
\hline Komerční banka & PSE & $\checkmark$ & $\checkmark$ & $\checkmark$ \\
\hline Moneta Money bank & PSE & & & \\
\hline $\mathrm{O} 2$ & PSE & & & \\
\hline Pegas Nonwovens & PSE & $\checkmark$ & $\checkmark$ & $\checkmark$ \\
\hline TMR & PSE & & & \\
\hline Unipetrol & PSE & & & \\
\hline VGP & PSE & & & \\
\hline VIG & PSE & & & \\
\hline NWR & PSE & $\checkmark$ & $\checkmark$ & $\checkmark$ \\
\hline $\mathrm{E} 4 \mathrm{U}$ & PSE & & & \\
\hline ENERGOAQUA & PSE & & & \\
\hline ENERGOCHEMICA & PSE & & & \\
\hline Jáchymov PM & PSE & & & \\
\hline Phillip Morris ČR & PSE & $\checkmark$ & $\checkmark$ & $\checkmark$ \\
\hline Pražské služby & PSE & & & \\
\hline RMS Mezzanine & PSE & & & \\
\hline TOMA & PSE & & & \\
\hline Photon Energy & PSE & & & \\
\hline Stock & PSE & $\checkmark$ & $\checkmark$ & $\checkmark$ \\
\hline Continental AG & DAX & $\checkmark$ & $\checkmark$ & $\checkmark$ \\
\hline Siemens & DAX & $\checkmark$ & $\checkmark$ & $\checkmark$ \\
\hline Lufthansa & DAX & $\checkmark$ & $\checkmark$ & $\checkmark$ \\
\hline
\end{tabular}

Note: CETV is regulated under US GAAP, and therefore was excluded in our research. 